\title{
Chromones and bischromones: an account of photoinduced reactions
}

\author{
Rupesh Kumar and Mohamad Yusuf* \\ Department of Chemistry, Punjabi University, Patiala-147002, Punjab, India \\ E-mail: dryusufpup@,rediffmail.com
}

\begin{abstract}
This account provides a survey of phototransformations of chromones occurring through the cycloadditions, oxidations, isomerizations and reorganizations. Photochemistry of the variety of bischromones occurring through intramolecular photo-H-abstractions and thus leading to angular tetracyclic photoproducts has also been reviewed. In the bischromones, the photoproduct formations and their distributions were found to be dependent upon the length and structure of the intermediate spacer units.
\end{abstract}

Keywords: Chromones, bischromones, phototransformations, H-abstraction

\section{Contents}

1. Introduction

2. Chromones

2.1 Photocycloaddition reactions

2.2 Photodimerization

2.3 Photoisomerization

2.4 Phototautomerization

2.5 Photorearrangement

2.6 Photoxidation and reduction reactions

2.7 Laser flash photolysis

2.8 Photoinduced $\mathrm{H}$-abstraction

2.8.1 3-Alkoxychromones

2.8.2 3-Allyloxychromones

2.8.3 Thiochromones

2.8.4 Styrylchromones

2.8.5 Spiropyrans

2.8.6 3-Naphthylmethoxychromones 
3. Bischromones

3.1 3-Alkoxybischromones: effect of length of intermediate spacer

3.2 p-Xylylbischromones

3.3 o-Xylylbischromones: proximity effect

4. Summary

5. Acknowledgements

6. References

\section{Introduction}

Chromones ${ }^{1}$ have been the subject of the considerable chemical interest in the past decades. They occur widely in nature and exhibit important biological as well as pharmacological activities. ${ }^{2}$ They are photochemically very active and lead to the generation of some exotic heterocyclic compounds. ${ }^{3}$ Flavonoids $^{4}$ are the chromones that are also most abundantly distributed in nature. Peucenin, ${ }^{5}$ eugenitol $^{6}$ and isoeugenitol ${ }^{7}$ are some commonly occurring chromones. The chromones are also well known for their antioxidant, ${ }^{8}$ biocidal, ${ }^{9}$ wound healing, ${ }^{10}$ anti-inflammatory, ${ }^{11}$ antiulcer, ${ }^{12}$ and immune-stimulatory ${ }^{13}$ activities. Recently, some chromones are also reported as anti-HIV agents. ${ }^{14}$ Khellin $^{15} \mathbf{1}$ and 2,4-thiazolidenedione ${ }^{16} \mathbf{2}$ are the chromones that are used as antispasmodic agent, in the treatment of anginapectoris and antidiabetic agent that improve peripheral insulin resistance in type-II diabetic patients respectively.
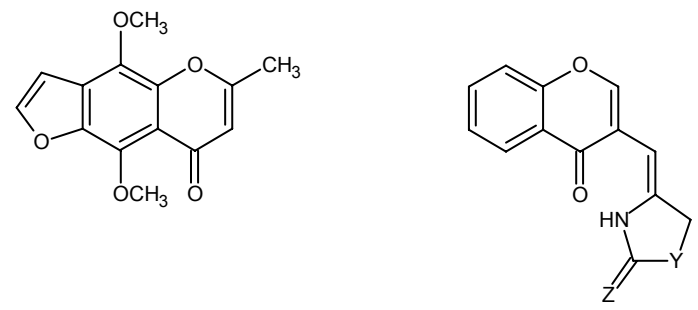

12

$\mathrm{Y}=\mathrm{S}, \mathrm{NH}, \mathrm{NMe}, \mathrm{NEt} ; \mathrm{Z}=\mathrm{O}, \mathrm{S}$

\section{Scheme 1}

These pharmacological activities have been the major incentives behind the synthesis of the chromones and their derivatives.

\section{Chromones}

As chromones are present in all parts of the plant kingdom, they are exposed to sun light for longer durations of time that make them liable to undergo some photo-structural transformations. 
As chromones are bichromophoric substrates that contain double bond as well as $\mathrm{C}=\mathrm{O}$ group as the chromophoric units which can undergo photo-excitation either in isolation or in conjugation.

Chromones are known to undergo photocycloaddition, photodimerisation, photoisomerisation, photoreararrangement, photooxidation-reduction and photocyclisation reactions involving both $\mathrm{n} \rightarrow \pi^{*}$ and $\pi \rightarrow \pi *$ transitions.

\subsection{Photocycloaddition reactions}

Photocycloaddition reactions of chromones with different olefins and related compounds are known to provide the products both through $[3+2]$ and $[2+2] \pi$ cycloaddition reactions. $[2+2] \pi$ photocycloaddition reactions are extensively studied by Hanifin and Cohen. ${ }^{17}$ These photoaddition reactions involve an electrophilic attack by C-3 of chromone involving $n \rightarrow \pi *$ triplet excitation with the fact that only phosphorescence is observed and no fluorescence is observed. It is consistent with the idea that intersystem crossing from $n \rightarrow \pi^{*}$ singlet to triplet should be rapid when singlet to triplet energy gap is small. ${ }^{18}$ Singlet- triplet energy gap for chromone in $2 \mathrm{M} \mathrm{THF}$ is only about $5-\mathrm{kcal} / \mathrm{mol}$.

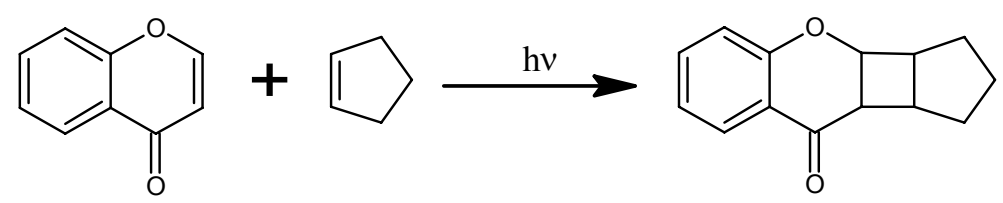

\section{Scheme 2}

Irradiation of a solution of chromone 4 with 1,1-dimethoxyethylene 5 gave photoproducts 6 and 7. But further studies have shown that 7 was a secondary photolysis product arising from 6.

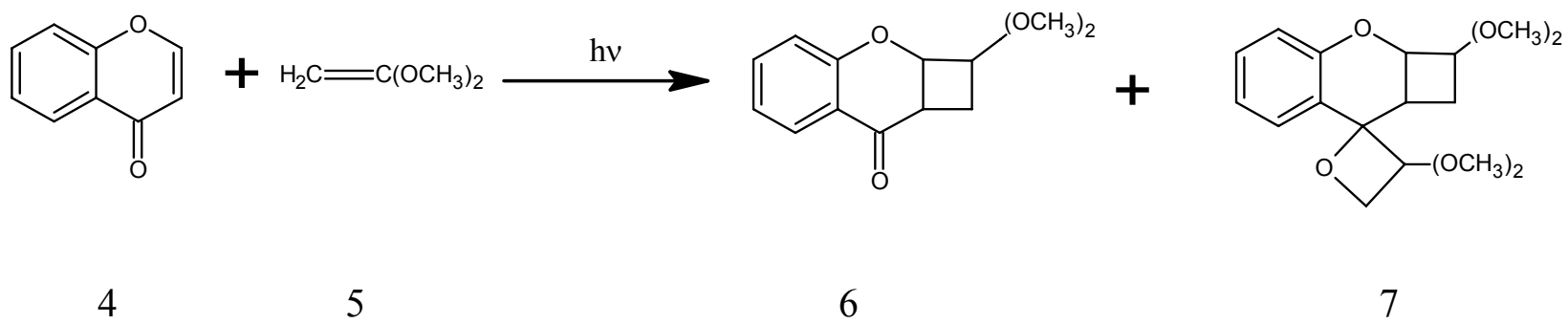

\section{Scheme 3}

Large-coupling constant for these photocycloaddition products by $[2+2] \pi$ addition revealed the cis orientation. ${ }^{19}$ The mechanism of cyclobutane formation is probably best described as an unsensetized $^{19 c}$ and electrophilic attack by $\mathrm{C}_{\alpha}$ of the $\mathrm{n} \rightarrow \pi^{*}$ chromone triplet on the most nucleophilic carbon atom of the olefin to give a 1,4-diradical intermediate such as $\mathbf{8 a}$ followed 
by formation of cyclobutane ring. Competition reaction might be depending upon the olefin used for initial $\mathrm{H}$-abstraction.

If $\alpha$ attack<smiles>COCCC1COc2ccccc2C1=O</smiles>

$8 a$

(Most stable)

If $\beta$ attack<smiles>CC(C)C1CC(=O)c2ccccc2O1</smiles>

$9 \mathrm{a}$

(Least stable)<smiles>COC1C[C@@H]2Oc3ccccc3C(=O)C12</smiles>

$8 \mathrm{~b}$

(Most stable)<smiles>COCCC1CC(=O)c2ccccc2O1</smiles>

$9 \mathrm{~b}$

(Most stable)

\section{Scheme 4}

\subsection{Photodimerization}

Mukerje $^{20}$ and coworkers have reported the phototransformation of 3-methoxychromone $\mathbf{1 0}$ where $\mathrm{H}$-abstraction coupled with dimerization has led to the formation of dimeric oxetanol 12.<smiles>COc1cc(OC)c2c(=O)c(OC)c([NH3+])oc2c1</smiles>

\section{Scheme 5}




\subsection{Photoisomerisation}

Under photolytic conditions, the chromones undergo fast enolisation. Upon the irradiation of 13a for 1-2 min., the orange photoenol 14a was formed which displayed a $\lambda_{\max }$ at $460 \mathrm{~m} \mu$. But orange color faded very quickly which led to the reformation of $\mathbf{1 3 a} \mathbf{.}^{21 \mathrm{a}}$<smiles>[R]C(CCCCC)c1oc2ccccc2c(=O)c1C(=O)c1ccccc1</smiles>

13<smiles>[R]C(CCCCCCC)=c1oc2ccccc2c(=O)c1=C(C)O</smiles>

14

(a) $\mathrm{R}=\mathrm{H}$

(b) $\mathrm{R}=\mathrm{C}_{6} \mathrm{H}_{5}$

\section{Scheme 6}

Upon longer irradiation of $\mathbf{1 4 a}$, the photoenolisation coupled with cyclisation led to tetracyclic product ${ }^{21 \mathrm{~b}} \mathbf{1 5}$.

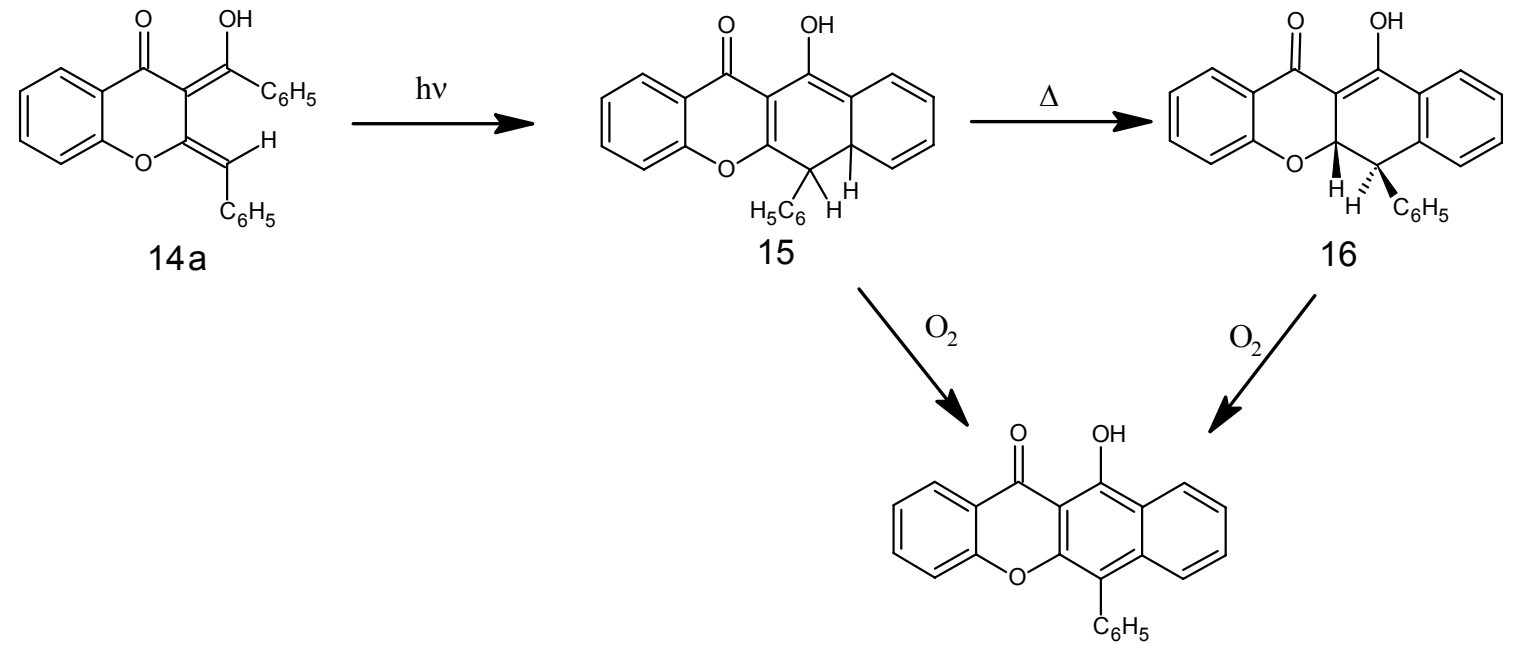

17

\section{Scheme 7}

But the intensive irradiation of $\mathbf{1 3 b}$ in the presence of oxygen provided the low yield of $\mathbf{1 4 b}$ along with a new photoproduct 18. 
<smiles>CCCCCCC(C)c1oc2ccccc2c(=O)c1C(=O)c1ccccc1</smiles>

$13 b$

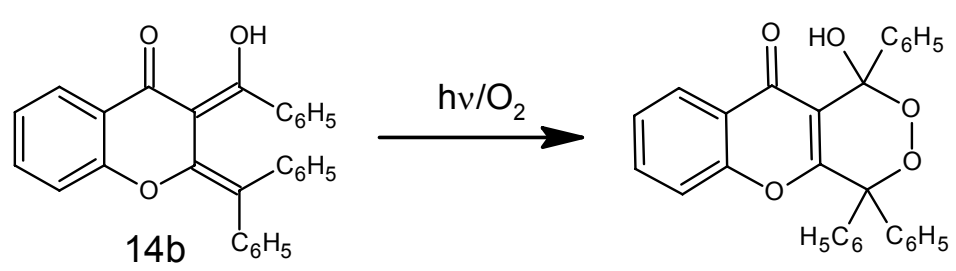

18

\section{Scheme 8}

\subsection{Phototautomerization}

The discovery of the excited-state proton transfer in 3-hydroxychromones, ${ }^{22}$ as shown in scheme 9 , has generated considerable interest in laser kinetic ${ }^{23}$ and piezospectroscopic ${ }^{24}$ study of the mechanism of phototautomerization. ${ }^{25}$<smiles>O=c1c(O)c(-c2ccco2)oc2ccccc12</smiles>

\section{Scheme 9}

\subsection{Photorearrangement}

3-Hydroxyflavone also undergo photorearrangement leading to the formation of indan-1,2diones. T. Matsuura et al. ${ }^{26}$ have done a detailed study of 3-hydroxy-2-arylchromones 24 which provided 3-aryl-1,2-indandiones $\mathbf{2 5}$ upon irradiation in 1:1 benzene-isopropyl alcohol with light above $290 \mathrm{~nm}$.

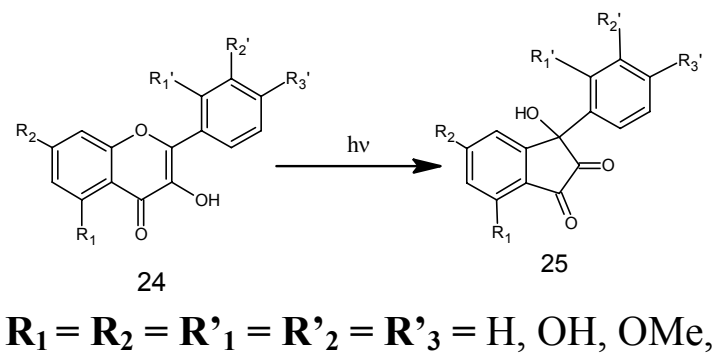

\section{Scheme 10}


The formation of $\mathbf{2 8}$ from $\mathbf{2 6}$ could be analysed through the intermediacy of 2,3-epoxy-2hydroxy-1-indanone 27 which can be formed by a formal $\left[\sigma^{2}+\pi^{2}\right]$ cycloaddition. $^{27}$

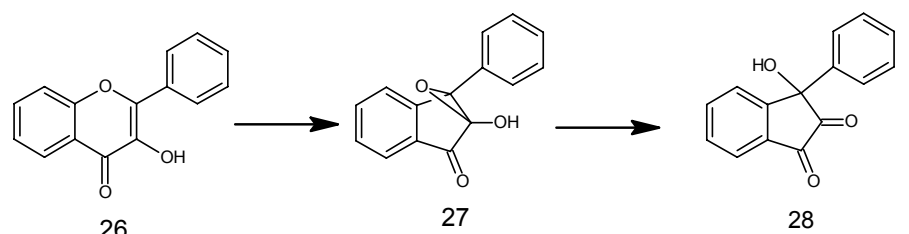

\section{Scheme 11}

Recently, some work has been done in our lab upon the photolysis of 3-hydroxy-2thienylchromone in cyclohexane ${ }^{28}$ that also resulted similar type of ring contracted photoproduct 30 .

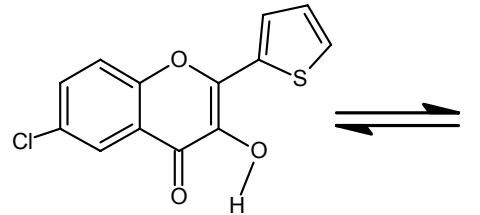

29<smiles>O=C1C(=O)C(O)(c2cccs2)c2ccc(Cl)cc21</smiles>

30

\section{Scheme 12}

\subsection{Photoxidation and reduction reactions}

Chromones are also liable to undergo photo-oxidation ${ }^{29}$ and photoreduction $^{30}$ that lead to a wide variety of products. Photo-oxidation of 3-hydroxyflavone $\mathbf{3 1}$ has been found to yield $\mathbf{3 2}$ and $\mathbf{3 3}$ as product through the reorganization and degradation.

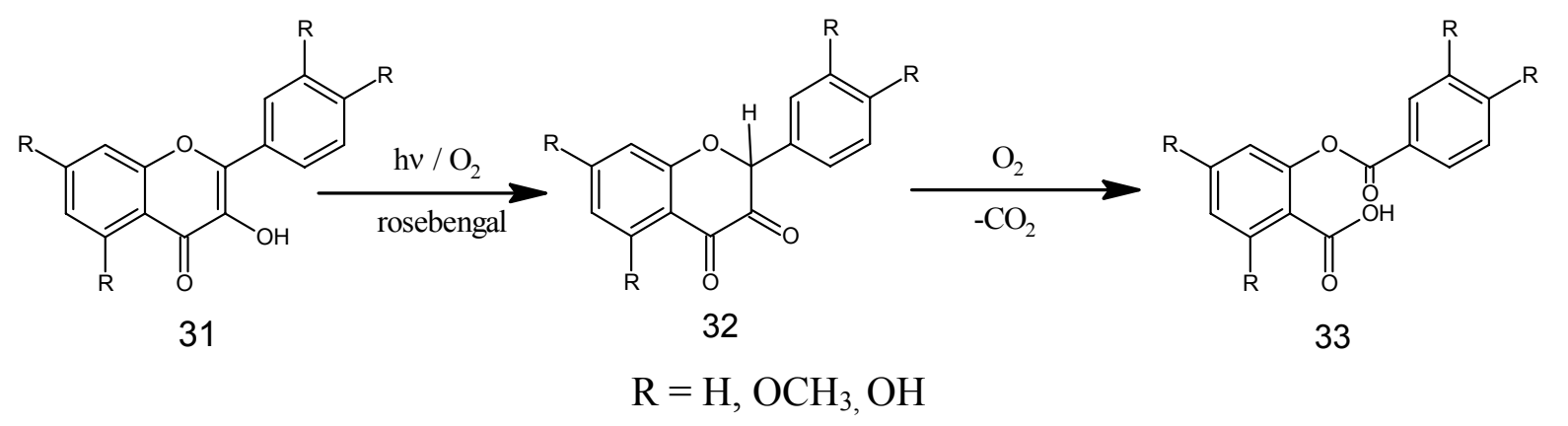

Scheme 13 
K. Ohara et $a l .{ }^{30}$ have made a detailed investigation on the photochemical reduction of chromones. Here, products $\mathbf{3 5}$ and $\mathbf{3 6}$ were obtained from the photoreduction of 2,3-double bond and $>\mathrm{C}=\mathrm{O}$ group respectively.

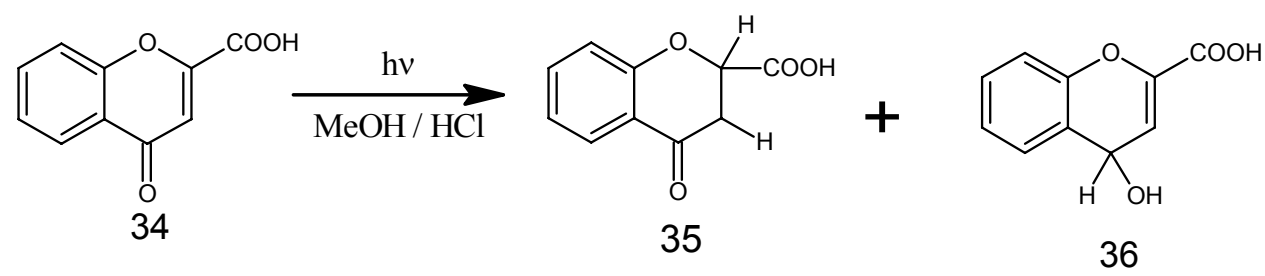

\section{Scheme 14}

\subsection{Laser flash photolysis}

The laser flash photolysis of simple substituted 4-pyrones 37, 2-phenylchromone $\mathbf{3 8}$ and 2,3diphenylchromone 39 resulted in the formation of short lived triplets $\left(\tau_{\mathrm{o}}{ }^{\mathrm{T}}=1-5 \mu \mathrm{s}, \lambda_{\max }=330-365\right.$ $\mathrm{nm})$ in high yields. ${ }^{31}$<smiles>Cc1oc(C)c(-c2ccccc2)c(=O)c1C</smiles>

37<smiles>CCCCCCCc1cc(=O)c2ccccc2o1</smiles>

38

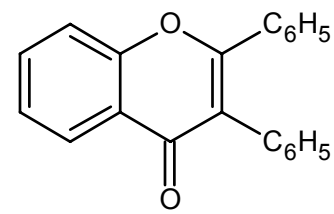

39

\section{Scheme 15}

But, at room temperature, the triplets of $\mathbf{3 7}$ and $\mathbf{3 9}$ were poorly quenched by 1methylnaphthalene $\left(\mathrm{E}_{\mathrm{T}}=59.6 \mathrm{Kcal} / \mathrm{mol}\right)$, diene $\left(\mathrm{E}_{\mathrm{T}}=59 \mathrm{kcal} / \mathrm{mol}\right)$ and ferrocene $\left(\mathrm{E}_{\mathrm{T}}=40 \mathrm{kcal} / \mathrm{mol}\right)$. In contrast, triplet of $\mathbf{3 8}$, which has a lower $\mathrm{E}_{\mathrm{T}}$ than $\mathbf{3 7}$ and $\mathbf{3 9}$, was very efficiently quenched by these molecules.

Spectroscopic triplet energies $\left(\mathrm{E}_{\mathrm{T}}\right)$ of $\mathbf{3 7}, \mathbf{3 8}$ and $\mathbf{3 9}$ were estimated as 69,62 and 67 $\mathrm{Kcal} / \mathrm{mol}$, respectively. The triplets of these $\mathbf{3 7}$ and $\mathbf{3 9}$ may probably undergo structural relaxation to geometric forms from which energy transfer to benzophenone would be of highly endothermic process.

There were difference in the behavior of triplets of two chromones 38 and 39. As it was evident from the quenching behaviors, the triplets of $\mathbf{3 8}$ that undergo very little or no relaxation while that in the case of $\mathbf{3 9}$ was pronounced. This difference was attributable to the fact that, while in the ground state the minimization of the nonbonding interaction involving the adjacent phenyl groups, occured through the partial twisting of the phenyl groups from the plane of chromone moiety, in the triplet excited state it was effected by twisting about the ene. 


\subsection{Photoinduced H-abstraction}

H-abstractions by the excited carbonyl chromophores have been the most investigated photochemical reactions. These $\mathrm{H}$-abstractions can be manipulated for the generation of some exotic heterocyclic compounds. ${ }^{32}$

\subsubsection{3-Alkoxychromones}

The phototransformations of the 3-alkoxychromones ${ }^{29} \mathbf{4 1}$ did not provide any ring contracted product $\mathbf{4 2}$ corresponding to $\mathbf{2 8}$ and 30, but resulted tetracyclic compound $\mathbf{4 0}$ which could be ascribed from the intramolecular $\mathrm{H}$-abstraction by photoexcited $\mathrm{C}=\mathrm{O}$ group.

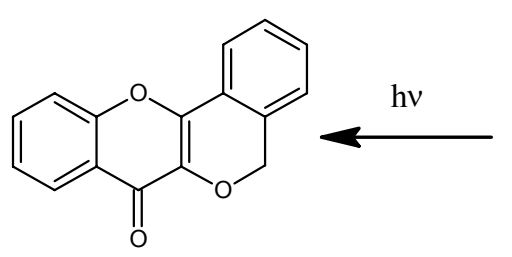

40

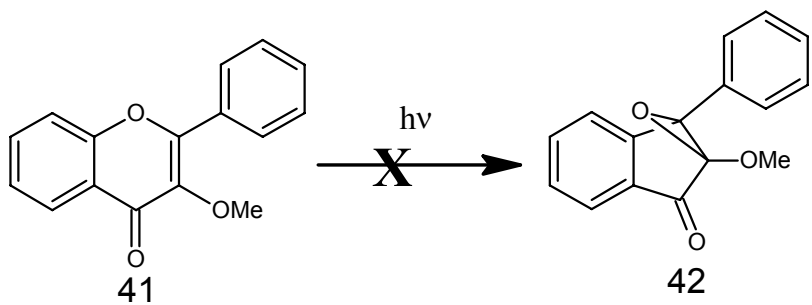

41

\section{Scheme 16}

A product similar to $\mathbf{4 0}$ has also been known to be formed from 3-methoxyflavones by irradiation either under nitrogen ${ }^{33}$ or oxygen. ${ }^{34}$ It is also reported that the 5-hydroxyl group Hbonded to the 4-carbonyl that causes photoresistance in flavonoids.

When 3-benzyloxy group was present at position 3 instead of methoxy 43, both dihydro 44 and aromatic $\mathbf{4 5}$ photoproducts were realized. 35,39,40 $^{2}$

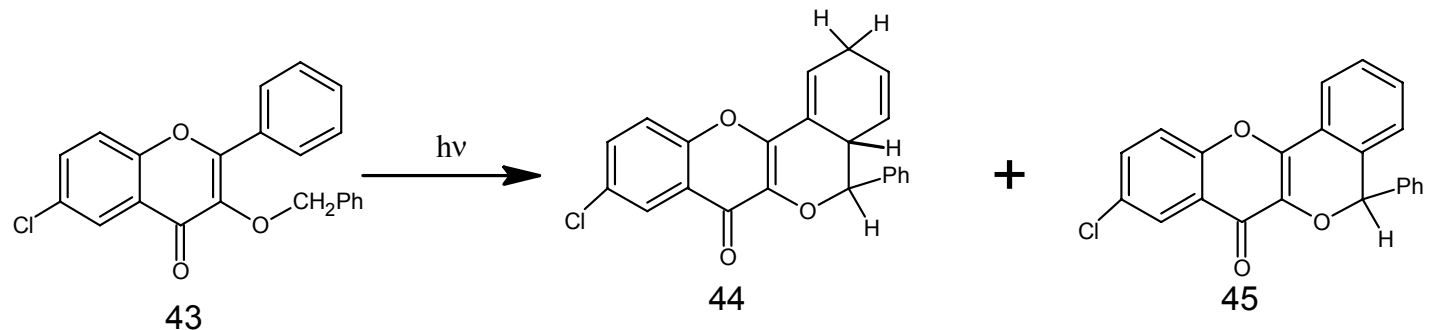

\section{Scheme 17}

Photoirradiation of a methanolic solution of 3-alkoxy-2-thienyl-4-oxo-4H-1-benzopyrans ${ }^{36}$ 46 with pyrex filtered UV light led to cyclised 47 and cyclodehydrogenated 48 angular products involving both thiophene and alkoxy groups similar to 44 and $\mathbf{4 5}$. 


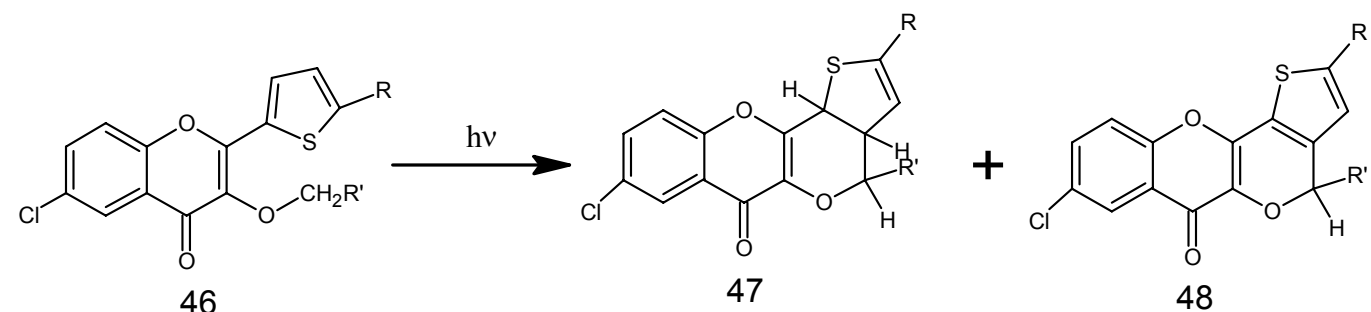

$$
\mathrm{R}=\mathrm{H}, \mathrm{CH}_{3} \quad \mathrm{R}^{\prime}=\mathrm{H}, \mathrm{CH}_{3}, \mathrm{C}_{6} \mathrm{H}_{5}
$$

\section{Scheme 18}

Here, product distributions depend upon the substituents on the thiophene ring. This study explained that (i) How a thiophene moiety (stabilization energy (SE) $32 \mathrm{Kcalmol}^{-1}$ affect the product formation/distribution compared with a furan $\left(\mathrm{SE}=16-18 \mathrm{Kcalmol}^{-1}\right)$ or phenyl moiety $\left(\mathrm{SE}=36 \mathrm{Kcalmol}^{-1}\right)$ at $\mathrm{C}-2$ and (ii) whether phototranspositions could become available in these photoreactions: a route common in the photolysis of 2-aryl/alkyl thiophenes. ${ }^{37}$

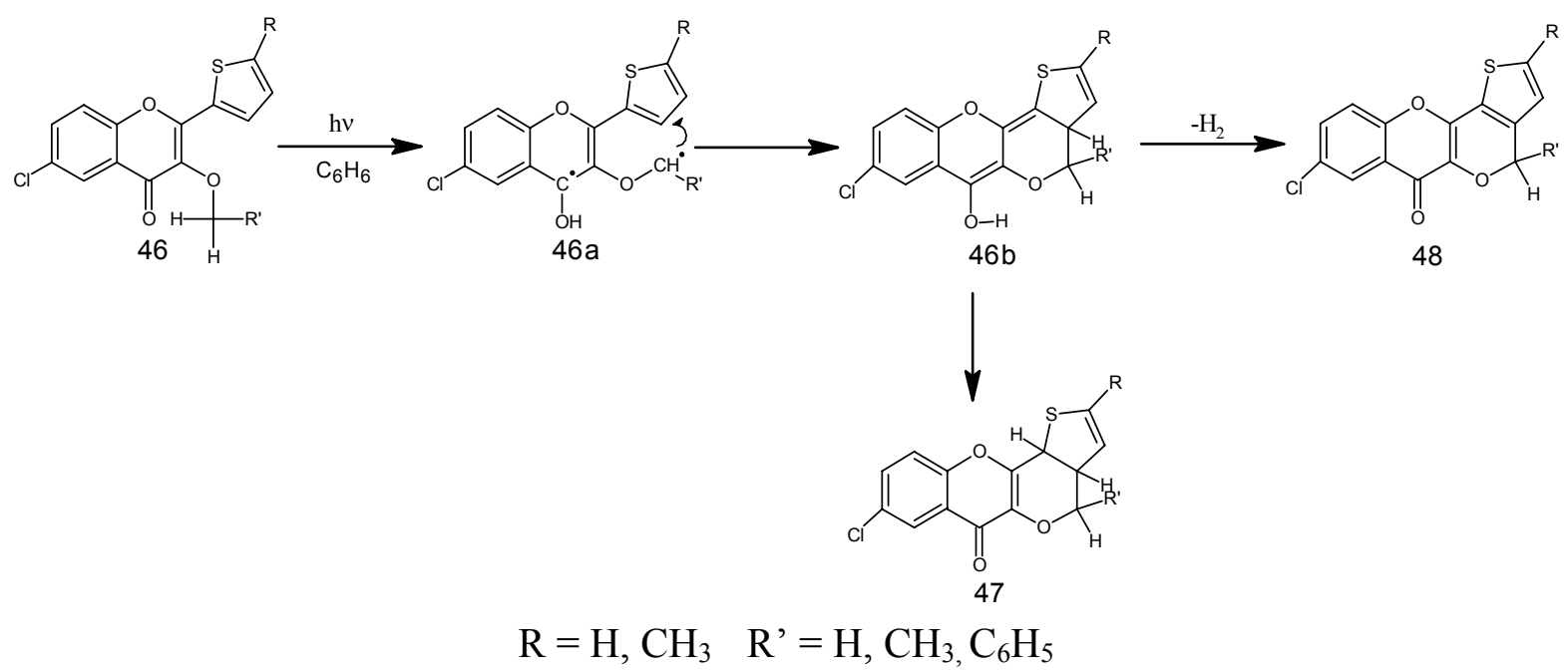

\section{Scheme 19}

Even the solvent polarity $\left(\mathrm{C}_{6} \mathrm{H}_{6}, \mathrm{MeOH}\right)$ did not have any significant influence on the product distributions. This suggests that the formation of $\mathbf{4 7}$ is intramolecular and probably occurs through a 1,5-sigmatropic migration, in enol 46a, formed initially by the abstraction of hydrogen from 3 -alkoxy group by the excited $\mathrm{C}=\mathrm{O}$ group of the pyrone moiety.

Regarding the effect of the substitution at $\mathrm{C}-2$ of the pyrone ring on product formation/distribution, an examination showed that in case of furyl, methylfuryl or methylthiophene chromones, only the photocyclised products similar to 47 were obtained. In others carrying phenyl or thiophene rings, both photocyclised, as 47 and photocyclodehydrogenated, as $\mathbf{4 8}$ are formed. For such results, the only assignable reason could be the difference in the electron density in the ring moiety at C-2. 
In phototransformations of 3-alkoxy-2-(2'-furyl)chromones ${ }^{38}$ in dry benzene, no dehydrogenated product was obtained as discussed above. The primary product was a dihydrofuryl derivative 49 that further underwent photoringcontraction ${ }^{39,40}$ to a cyclopropyl carbonyl compound 50. When photoirradiation was carried out in $\mathrm{MeOH}$, then photoproduct 51 was also realized along with the $\mathbf{4 9}$ and $\mathbf{5 0 .}$<smiles>[R]C1=C[C@@]2([R])Cc3oc4ccc(Cl)cc4c(=O)c3O[C@@H]2O1</smiles>

49<smiles></smiles>

50<smiles>[Z]C1([2H])Oc2c(oc3ccc(Cl)cc3c2=O)CC1CC(C)=O</smiles>

51

$$
\begin{aligned}
\mathrm{R} & =\mathrm{H}, \mathrm{CH}_{3} \\
\mathrm{R}^{\prime} & =\mathrm{H}, \mathrm{C}_{6} \mathrm{H}_{5}
\end{aligned}
$$

\section{Scheme 20}

\subsubsection{3-Allyloxychromones}

These intramoleculer H-abstractions have also been studied on the 3-allyloxy-chromone like Karanjin and their derivatives, ${ }^{41}$ as shown in scheme 17.

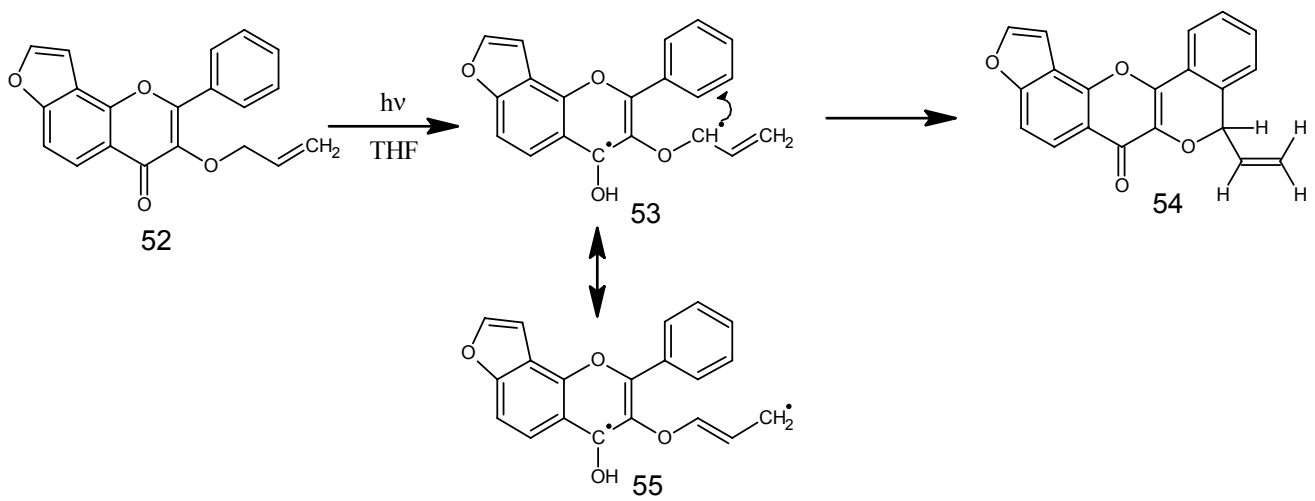

\section{Scheme 21}

Here, the photoproduct 54 was obtained only from the 1,4-biradical 53 and 1,6-biradical 55 did not provide any such product. Further, some work has been done upon the photochemical transformations of 3-allyloxy-2-phenyl ${ }^{57} 56 /$ furyl $^{42} 59$ / thienyl ${ }^{43} 62$ chromones.

Here, again the formation of photoproducts 57 and 58 from 56 and 60 \& 61 from 59, as shown in scheme 22, could be analyzed only through the involvement of 1,4-biradicals. 
<smiles>[R]C([R3])=C([R3])COc1c(-c2ccc([R])cc2)oc2ccc(Cl)cc2c1=O</smiles>

56

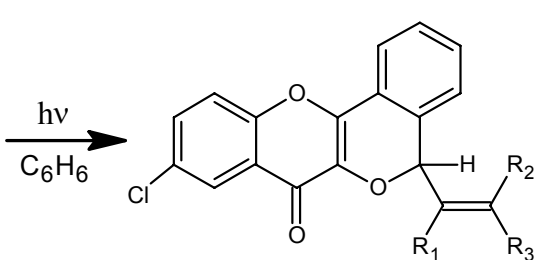

57

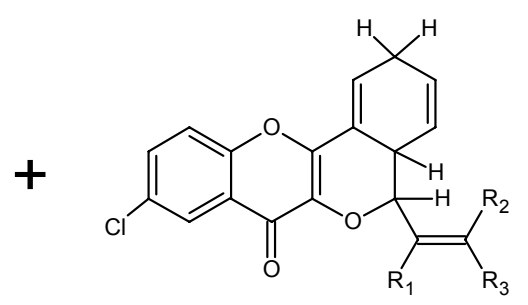

58

$$
\begin{gathered}
\mathrm{R}=\mathrm{H}, \mathrm{CH}_{3}, \mathrm{OCH}_{3} \\
\mathrm{R}_{1}=\mathrm{R}_{2}=\mathrm{R}_{3}=\mathrm{H}, \mathrm{CH}_{3}
\end{gathered}
$$

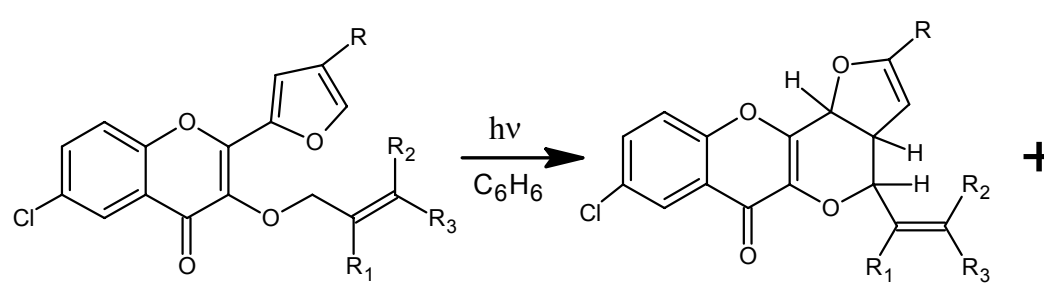

60<smiles>[R]C(=O)[C@H]1[C@H]2c3oc4ccc(Cl)cc4c(=O)c3O[C@H](C([R])=C([R])[R3])[C@@H]21</smiles>

61

59

$$
\begin{gathered}
\mathrm{R}=\mathrm{H}, \mathrm{CH}_{3} \\
\mathrm{R}_{1}=\mathrm{R}_{2}=\mathrm{R}_{3}=\mathrm{H}, \mathrm{CH}_{3}
\end{gathered}
$$

\section{Scheme 22}

Mechanistically, the formation of photoproduct $\mathbf{6 1}$ may be ascribed again from the ring contraction $^{38}$ of the dihydroproduct $\mathbf{6 0}$, it could not be directly obtained from the photolysis of 59. That was conformed from the observations that further photoirradiation of 60 provided 61 as the photoproduct. Photolysis of 2-thienyl-3-allyloxy-chromones $\mathbf{6 2}$ under similar conditions also furnished tetracyclic photoproducts 63 and 64.<smiles>[R]C([R])=C(Br)COc1c(-c2cc([R])cs2)oc2ccc(Cl)cc2c1=O</smiles>

62

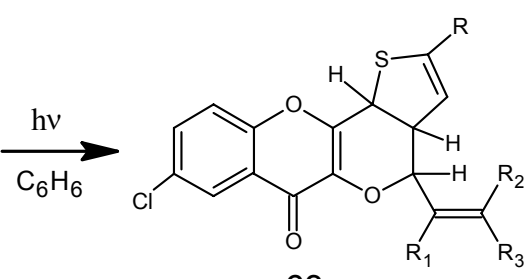

63<smiles>[R]C([R3])=C([R])C1([R])Oc2c(oc3ccc(Cl)cc3c2=O)-c2sc([R])cc21</smiles>

64

$$
\begin{gathered}
\mathrm{R}=\mathrm{H}, \mathrm{CH}_{3} \\
\mathrm{R}_{1}=\mathrm{R}_{2}=\mathrm{R}_{3}=\mathrm{H}, \mathrm{CH}_{3}
\end{gathered}
$$

\section{Scheme 23}

When electron captive group (-COOEt) was present upon the allyloxy group $\mathbf{6 5}$, then initially formed 1,4-biradical 66 undergo mesomerization to yield vinyl ethers as the photoproduct, ${ }^{44} \mathbf{6 7}$. 
Many methods are available ${ }^{45,46}$ to obtain vinyl ethers, but this is the simplest method among them.

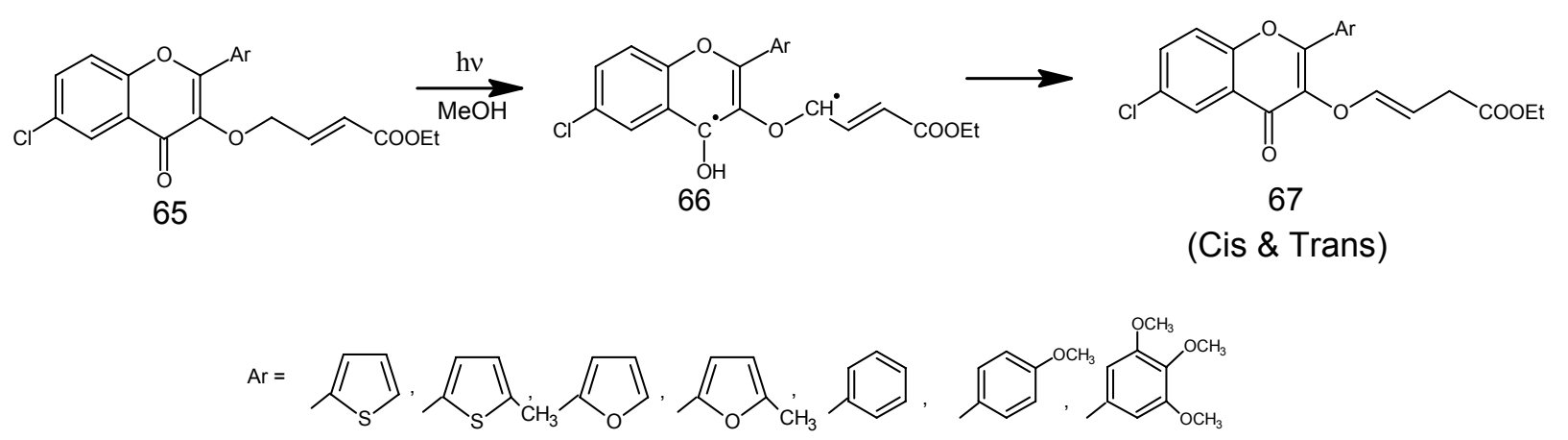

\section{Scheme 24}

\subsubsection{Thiochromones}

We have also studied the photolysis of some 3 -alkoxy-thio-chromones ${ }^{47} \mathbf{6 8}$ to see the effect of thiocarbonyl chromophore $(>\mathrm{C}=\mathrm{S})$ in comparison to carbonyl group $(>\mathrm{C}=\mathrm{O})$ upon the photochemical H-abstraction. Here, again tetracyclic photoproduct 71 was realized.<smiles>[R]COc1c(-c2cccs2)oc2ccc(Cl)cc2c1=O</smiles>

68

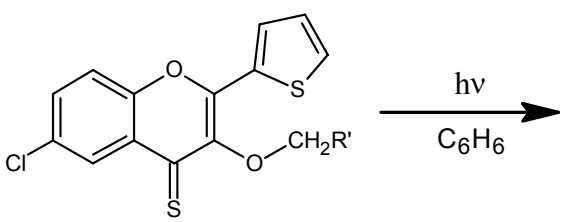

70

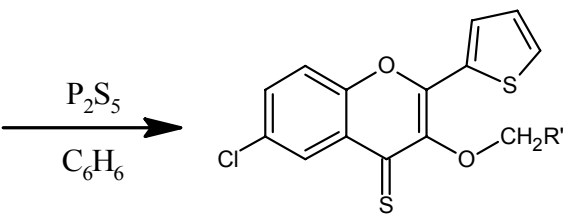

69<smiles>[R]C1([2H])Oc2c(oc3ccc(Cl)cc3c2=S)-c2sccc21</smiles>

71

(a) $\mathrm{R}^{\prime}=\mathrm{H}, \mathrm{CH}_{3}$

(b) $\mathrm{R}^{\prime}=\mathrm{C}_{6} \mathrm{H}_{5}$

\section{Scheme 25}

Similar aromatic photoproducts were formed when phenyl or substituted phenyl group was present at 2-position of thiochromone (69a \& 69b) and similar chromones having $\mathrm{R}^{\prime}=\mathrm{H}, \mathrm{CH}_{3}$ and phenyl at $\mathrm{C}-2$ position did not show any photoreactivity. The above photoreactions can be envisaged as being initiated through $\mathrm{H}$-abstraction from 3-alkoxy group by excited $\mathrm{C}=\mathrm{S}$, for the $\mathrm{H}$-abstraction, the energy of the excited $\mathrm{C}=\mathrm{S}$ group and the strength of 3-O-C-H bond need to be 
compatible. The energy of the excited thiones ${ }^{48}$ is known to be between $160-200 \mathrm{KJmol}^{-1}$. In aromatic and unstrained cyclic thiones these states lie well below the threshold for intramolecular chemical transformations, the quantum yield of net photochemical consumption of $4 H$-1-benzopyrone-4-thione ${ }^{49}$ is $5 \times 10^{-4}$. Thus activation of $\mathrm{C}-\mathrm{H}$ bond is necessary for reaction to occur. Though in chromones containing carbonyl group the $\mathrm{H}$ to be abstracted from 3-alkoxy group is activated by $\mathrm{O}$-atom, does not seem to be adequate. A further activation is necessary and a phenyl group provides that.

\subsubsection{Styrylchromones}

Phototransformations of some styrylchromones have also been studied in detail. ${ }^{50} 3$-alkoxy-2styrylchromones on photoirradiation with UV light transformed into oxetanopyranones, pyranopyrones and pyranoalcohols. The products formed have been found to depend upon the structure of alkoxy group (methyl, benzyl and allyl) present at the $\beta$-position of the enone moiety. 6-chloro-3-methoxy-2-styrylchromone $\mathbf{7 2}$ on photoirradiation with pyrex filtered UV light furnished three products $\mathbf{7 3}, \mathbf{7 4} \& \mathbf{7 5}$.

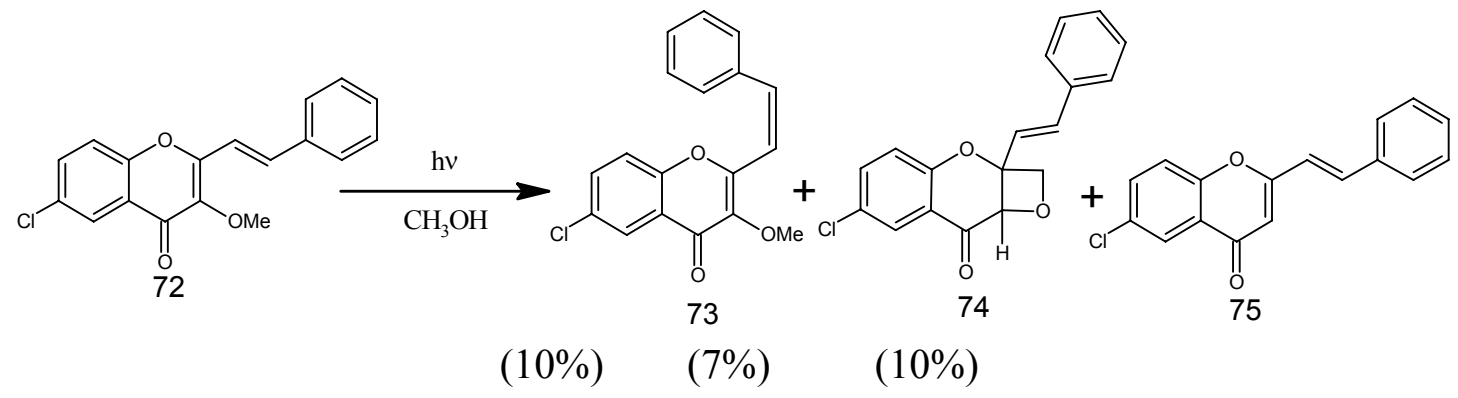

\section{Scheme 26}

On photoirradiation of 3-benzyloxy-2-styrylchromone $\mathbf{7 6}$ only a linear tricyclic pyranopyrone 77 photoproduct was obtained in 10\% yield and no other compound could be isolated.<smiles>O=c1c(OCc2ccccc2)c(/C=C/c2ccccc2)oc2ccc(Cl)cc12</smiles>

76<smiles>CO[C@H](C)[C@H](O)c1ccc2oc3c(c(=O)c2c1)O[C@H](c1ccccc1)[C@H](c1ccccc1)C3</smiles>

77

\section{Scheme 27}

Similarly, photoirradiation of other styrylchromone $\mathbf{7 8}$ provided following three photoproducts 79, $\mathbf{8 0}$ and $\mathbf{8 1}$. Out of which two are linear and one is angular. 


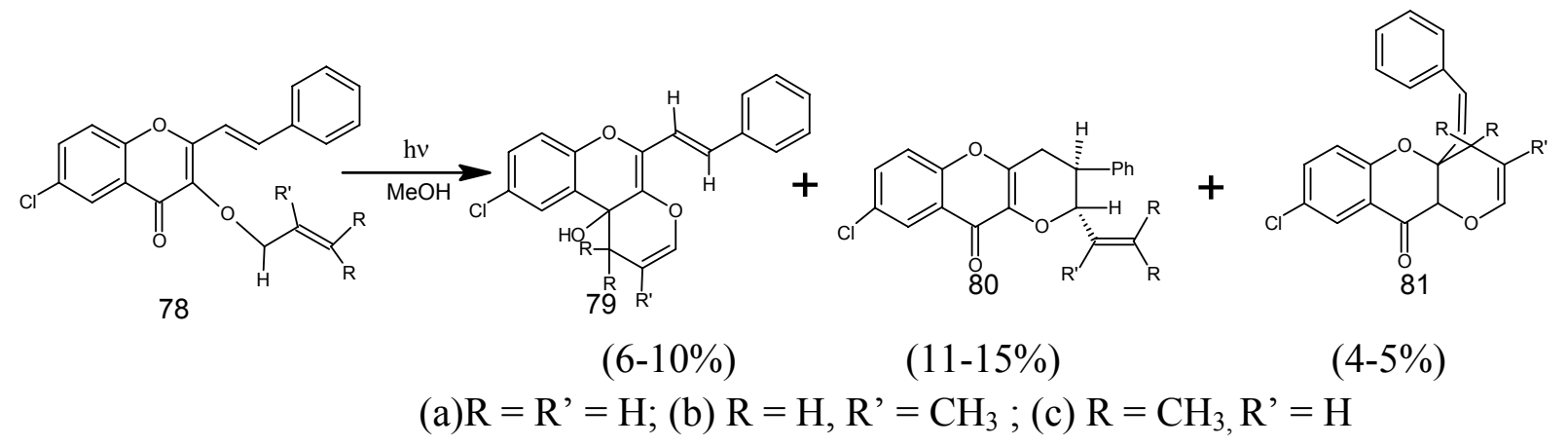

Scheme 28

But when the styrylchromones containing electron rich heterocycles (thiophene, furan) in place of phenyl at C-2 were photoirradiated, then only compound that could be isolated were angular tricyclic pyranoalcohols $82 .{ }^{51,52}$

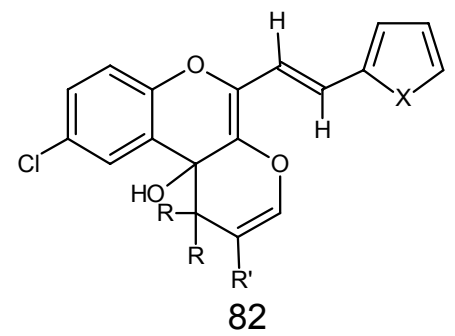

$(4-10 \%)$

(a) $\mathrm{R}=\mathrm{H}, \mathrm{R}^{\prime}=\mathrm{H}, \mathrm{X}=\mathrm{S}$; (b) $\mathrm{R}=\mathrm{H}, \mathrm{R}^{\prime}=\mathrm{CH}_{3}, \mathrm{X}=\mathrm{S}$

(c) $\mathrm{R}=\mathrm{H}, \mathrm{R}^{\prime}=\mathrm{H}, \mathrm{X}=\mathrm{O}$; (d) $\mathrm{R}=\mathrm{H}, \mathrm{R}^{\prime}=\mathrm{CH}_{3}, \mathrm{X}=\mathrm{O}$

\section{Scheme 29}

Generally, these photo-conversions have also been rationalized through an initial $\mathrm{H}-$ abstraction by $\mathrm{C}=\mathrm{O}$ group producing a 1,4 -biradical ${ }^{35,36,53}$ but in allyloxy derivatives, cyclisations involved both 1,4 and 1,6-biradicals.

\subsubsection{Spiropyrans: photochemical synthesis}

Spirocyclic systems find extensive uses in various fields ${ }^{54}$ developed earlier by various methods. ${ }^{55}$ A photochemical approach, as shown in scheme 30, towards the synthesis of complex spiropyrans $^{56}$ has been developed. 
<smiles>[R]c1cc2c(c([R])c1[R])-c1oc3ccc(Cl)cc3c(=O)c1OC1(C=CCCC1)C1=CC(C)=C(OC3C=CCCC3)C(=O)C1=C2</smiles>

83

84

$$
\begin{gathered}
\mathrm{n}=1,2 \\
\mathrm{R}=\mathrm{H}, \mathrm{OCH}_{3}
\end{gathered}
$$<smiles>O=c1c(OC2C=CCC2)c(-c2cccs2)oc2ccc(Cl)cc12</smiles>

85

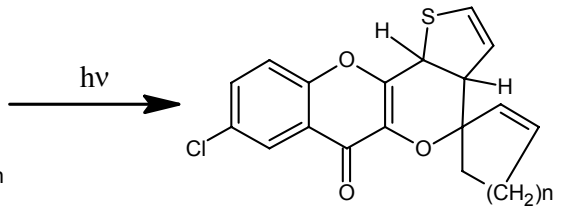

86

$\mathrm{n}=1,2,3$

\section{Scheme 30}

\subsubsection{3-Naphthylmethoxychromones: Effect of substituent}

In a recent study in our laboratory, ${ }^{57}$ we have observed the effect of various substituents of 3alkoxy group upon the photoproduct formations. Photoirradiation of 3-naphthylmethoxy-2thienyl/furyl-chromone 87 under the $\mathrm{N}_{2}$ environment for a just 25-30 minutes led to $85-90 \%$ conversion of the reactant into tetracyclic photoproducts $\mathbf{8 8}(45-50 \%)$ and $\mathbf{8 9}(20-25 \%)$.

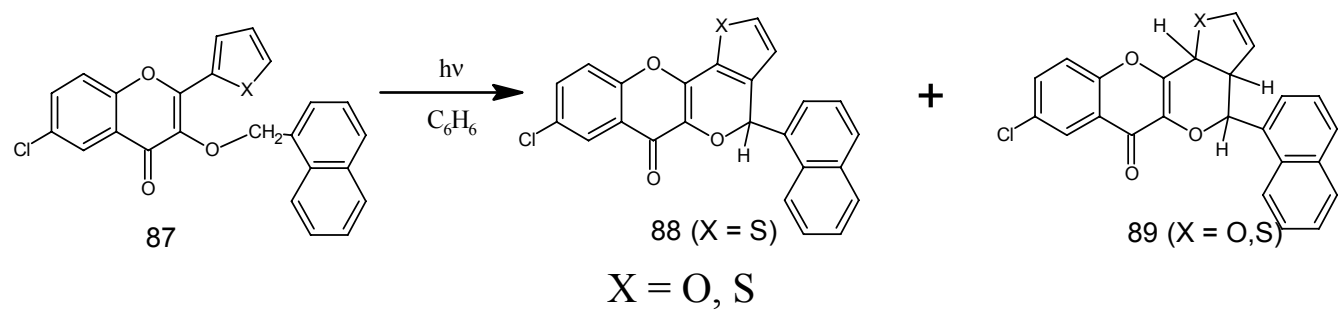

\section{Scheme 31}

Similar photoirradiation of 2-phenyl-3-naphthylmethoxy-chromones 90 resulted the formation of hydrogenated 92 (20-25\%) and dehydrogenated 91 (40-45\%) tetracyclic products. 


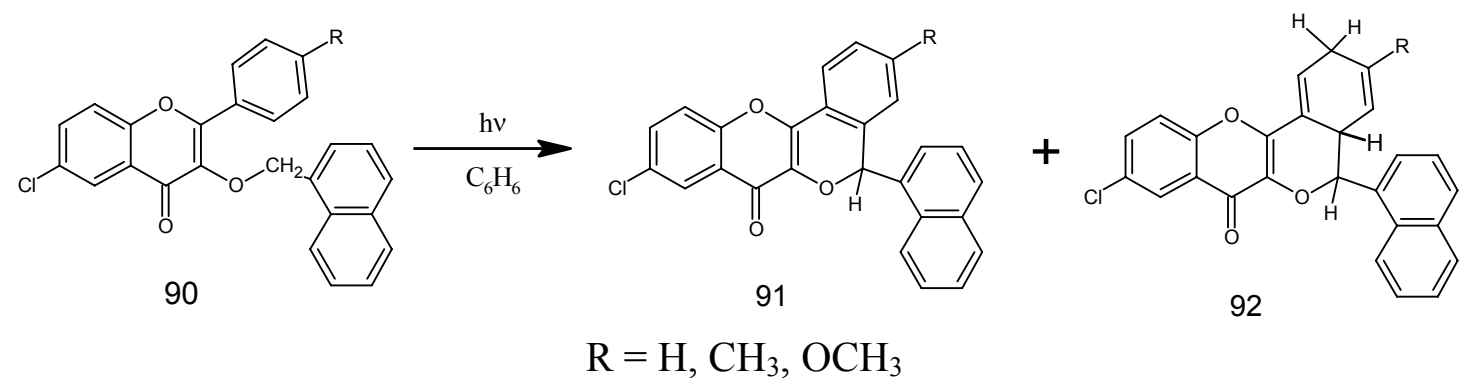

\section{Scheme 31a}

The better yields of the photoproducts in the above cases could be explained on the basis of the higher stabilities of 1,4-biradicals 99, provided by the naphthalene moiety, involved in these photoreactions. But, when the naphthalene moiety was replaced by an electron captive group (COOEt) 93, then photoirradiation ${ }^{57}$ resulted in the very low yields of the tetracyclic photoproducts 94 (10\%) and 95 (5\%) and always about $80 \%$ of starting material was recovered unreacted. Inspite of our best efforts, we were unable to isolate any cyclopropyl carbonyl derivative similar to 50, from the photolysis of 2-furylchromones $\mathbf{8 7}$ and $\mathbf{9 3 .}$<smiles></smiles>

93

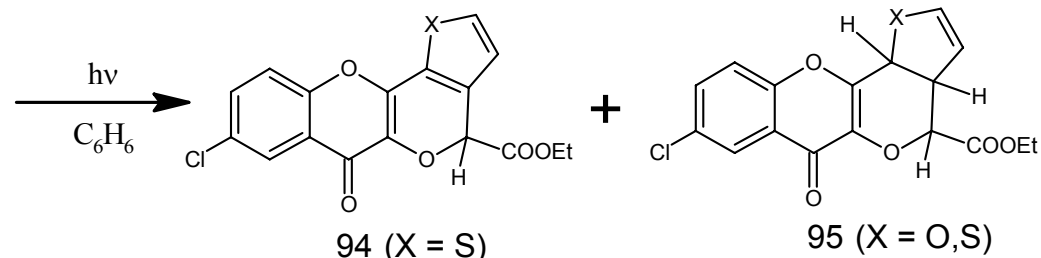

$\mathrm{X}=\mathrm{O}, \mathrm{S}$

\section{Scheme 31b}

Similar results (97 and 98) were observed when 2-phenylchromones 96 were photoirradiated in benzene, as shown in scheme 32. These observations may be ascribed to the lesser stability of the intermediate 1,4-biradical $\mathbf{1 0 0}$ than 99. Here, it appears that radical stabilizing effect of the ester group is offset by its inductive effect. ${ }^{58}$

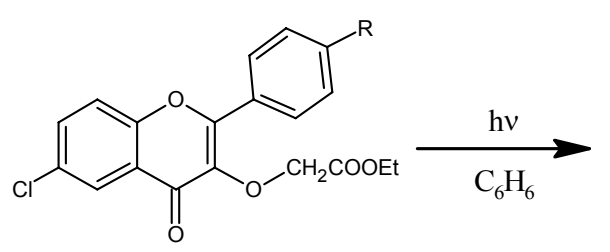

96<smiles>[R]c1ccc2c(c1)C(C(=O)OCC)Oc1c-2oc2ccc(Cl)cc2c1=O</smiles>

97<smiles>[R]C1=CC2(C)C(OCC)=CC([2H])C=C2c2oc3ccc(Cl)cc3c(=O)c2OC1</smiles>

98

Scheme 32

$$
\mathrm{R}=\mathrm{H}, \mathrm{CH}_{3}, \mathrm{OCH}_{3}
$$




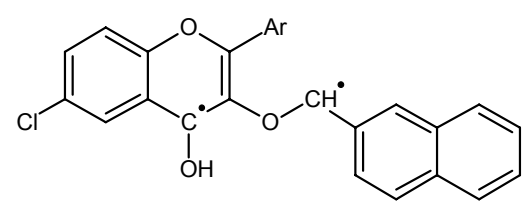

99

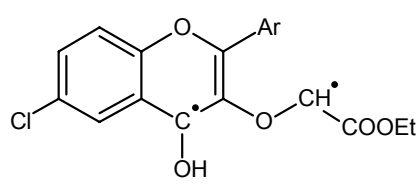

100

$$
\mathrm{R}=\mathrm{H}, \mathrm{CH}_{3}, \mathrm{OCH}_{3} \text { and } \mathrm{X}=\mathrm{O}, \mathrm{S}
$$

\section{Scheme 32a}

\section{Bischromones}

Bischromones are the bichromophoric compounds that are formed by joining the two chromone nuclei together through the carbon chains of varying length and structure. Some of the

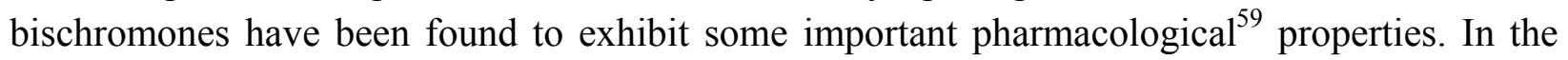
literature, some methods are reported about the synthesis of bischromones, which are either very difficult or may require some very precious and toxic reagents. ${ }^{60-62}$ But, in our lab, a very general and simple approach has been developed for the synthesis of bischromones. ${ }^{63}$ These synthesis were carried out in the presence of $\mathrm{Bu}_{4} \mathrm{~N}^{+} \mathrm{I}^{-}$as PTC which not only decreased the reaction time drastically but also improved the yield of the bischromones. Bischromones are also photochemically active specially their 3-alkoxy derivatives.

\subsection{3-Alkoxybischromones: Effect of length of intermediate spacer}

Recently we have reported solution phase photolysis of 3 -alkoxy-2-phenyl/thienyl $l^{63} /$ furyl $^{42}$ bischromones, as shown in scheme 33 and 34. Our interest in these photoreactions were many folds: (i) 2,3- double bond of pyrone ring may undergo intramolecular [2+2] photocycloaddition reaction (ii) Photoreactions may be initiated through the $\gamma$-H-abstraction by the photo excited carbonyl $(\mathrm{C}=\mathrm{O})$ chromophore from $-\mathrm{OCH}_{2}$-group. The behavior of these bischromones towards photolysis seems dependent upon the length of the alkyl chain joining the two chromone nuclei. That is, there is no reaction when $n=0$, reaction occurs only on one side when $n=1$ and 2 , and involves both sides of the molecules when $n=3$ and $8 .{ }^{43}$ This may be rationalized on the basis of intramolecular complex formation between the two chromone moieties in these molecules. Herein, the governing factor could be the lifetime of the excited states involved and the free energy change accompanying the reactions. The possibility of the formation of the intramolecular complex is limited by the probability of overlapping of the two nuclei bearing the chromophores in the lifetime of the excited states involved. An intramolecular complex 
formation can lead to the deactivation. An increase in the length of intervening alkyl chain shall increase the number of rotamers. Consequently, this decreases the tendency of intramolecular complex formation and deactivation of the excited state in turn. This is corroborated by the observation that the recovery of the starting bischromones was more than the $95 \%$ when $n=0$, $\sim 60 \%$ when $n=1$ or $2, \sim 20 \%$ when $n=3$ and only $5 \%$ when $n=8 .{ }^{43}$ Although the possibility of the formation of the photoproducts similar to $\mathbf{1 0 4}$ and $\mathbf{1 0 5}$ from bischromones 101 ( $\mathrm{n}=1$ and 2) can not altogether be excluded, we were unable to isolate such products. However, investigations upon the photolytic behavior of the biscoumarins ${ }^{64-66}$ and bispyrones ${ }^{67}$ the intramolecular cycloadditions involving the double bond of the pyrone ring have been reported; however in this study, no such intramolecular [2+2] photocycloaddition was observed and reaction occurred only through the H-abstractions. The intermolecular [2+2] photocycloadditions on 4-oxo-4H-pyrones is well documented. ${ }^{17,19,68}$

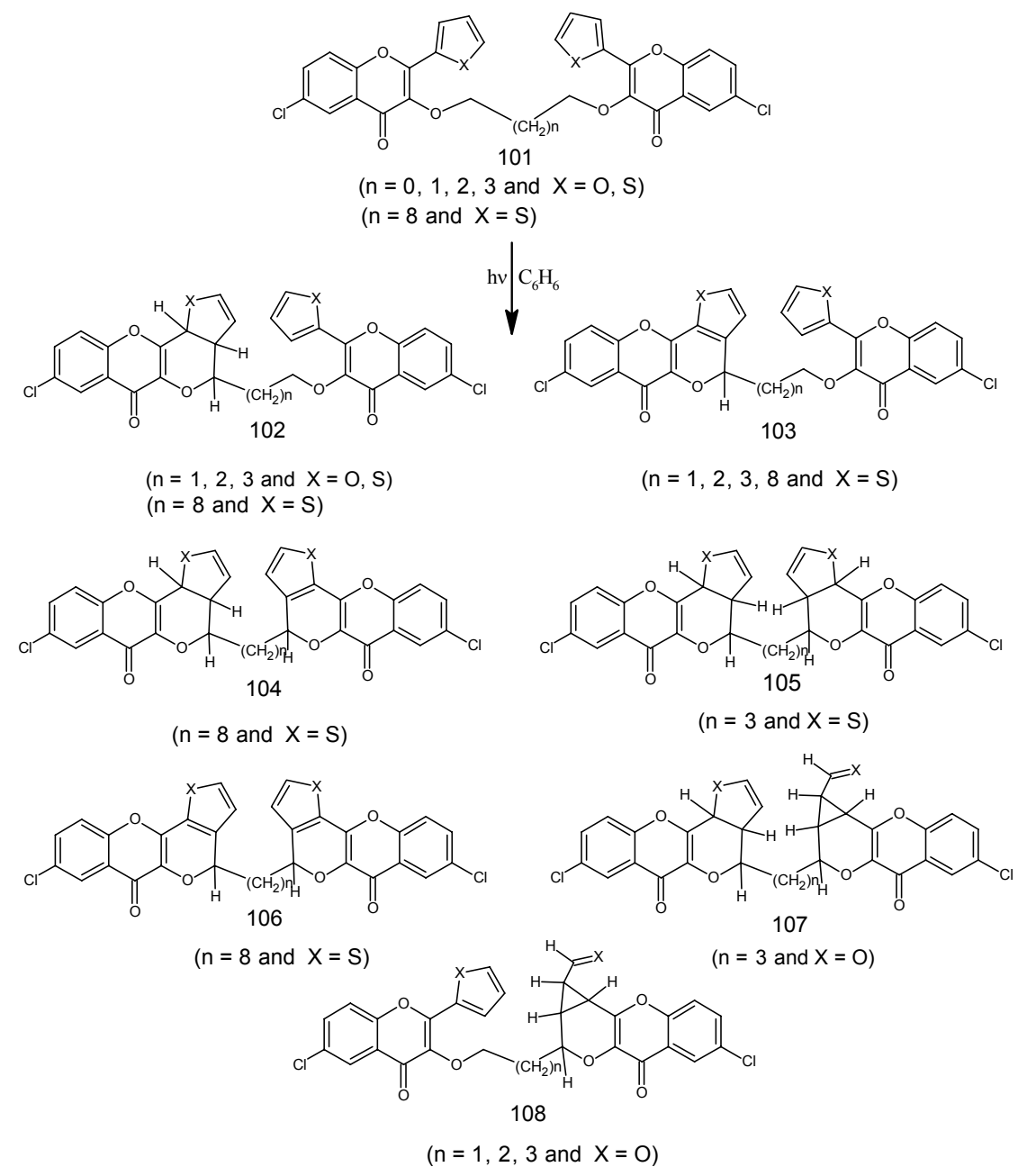

Scheme 33 
General Papers

ARKIVOC 2006 (ix) 239-264<smiles>O=c1c(OCCCCCCCCCCOc2c(-c3ccccc3)oc3ccc(Cl)cc3c2=O)c(-c2ccccc2)oc2ccc(Cl)cc12</smiles>

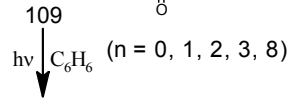

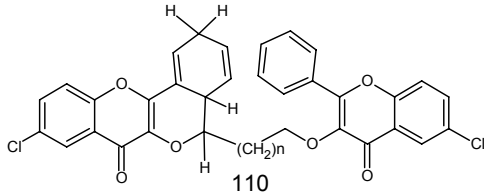

$(\mathrm{n}=1,2,3,8)$

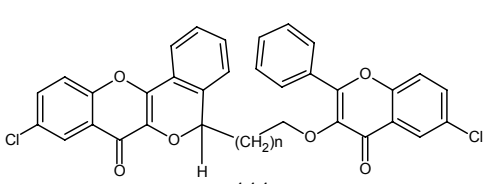

$(\mathrm{n}=111,2,3,8)$

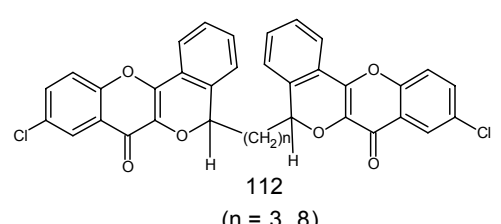

$(\mathrm{n}=3,8)$

Scheme 34

3.2 p-Xylylbischromones

Further to study the behaviour of the intermediate 1,4-biradicals and affect of their stabilities upon the photoproduct formations and their distributions, these phototransformations were extended upon the bischromones built around p-xylyl moiety. ${ }^{69}$

In these bischromones also the photoproduct could be realized only through the intramolecular photo-H-abstraction. But, it is important to mention here that the photolysis of 113 and 117 provided the better yields of the resulting photoproducts 114-16 and 118-20 in comparison to similar photoproducts obtained from 101 and 109. This could be ascribed to the greater stabilities of benzylic-1,4-biradicals involved in $\mathbf{1 1 3}$ and 117 than the alkyl 1,4-biradicals produced by $\mathbf{1 0 1}$ and 109.

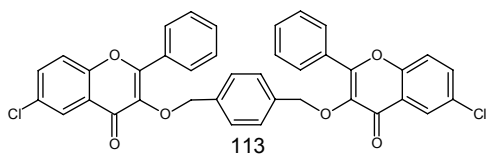

$h v \mid \mathrm{C}_{6} \mathrm{H}_{6}$
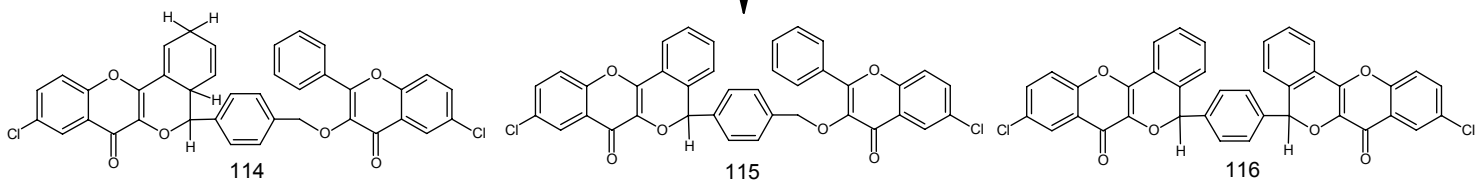

Scheme 35

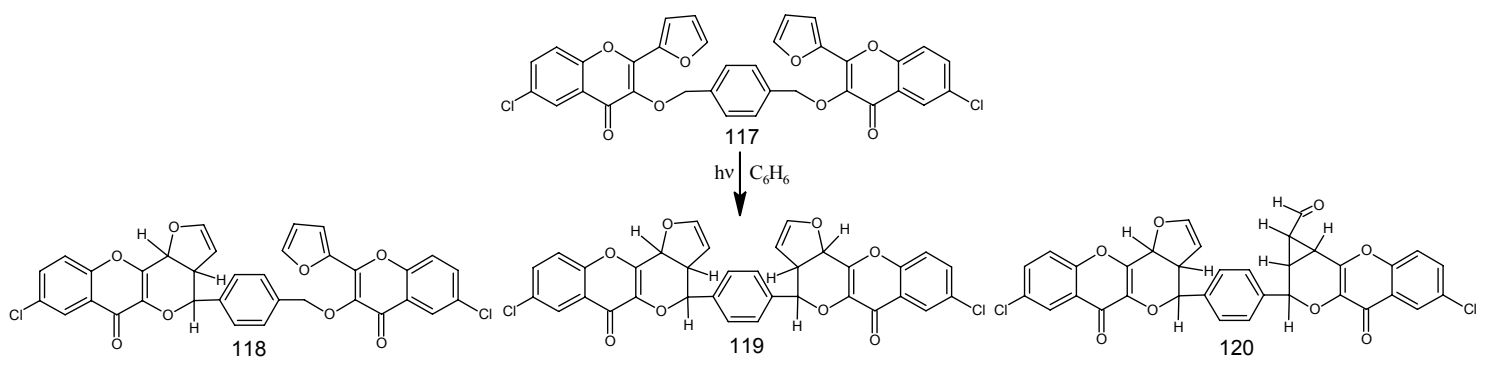

Scheme 36

ISSN 1424-6376

Page 258

${ }^{(c)}$ ARHAT 


\section{3 o-Xylylbischromones: proximity effect}

In a recent study, photoirradiation of bischromones built around o-xylyl moiety ${ }^{70}$ showed the greater proximity effect and the restricted conformational mobility of the two chromophores on the photoreactions. When o-xylylbischromones 121 were photoirradiated, it resulted 122, 123 and $\mathbf{1 2 4}$ as the photoproducts.

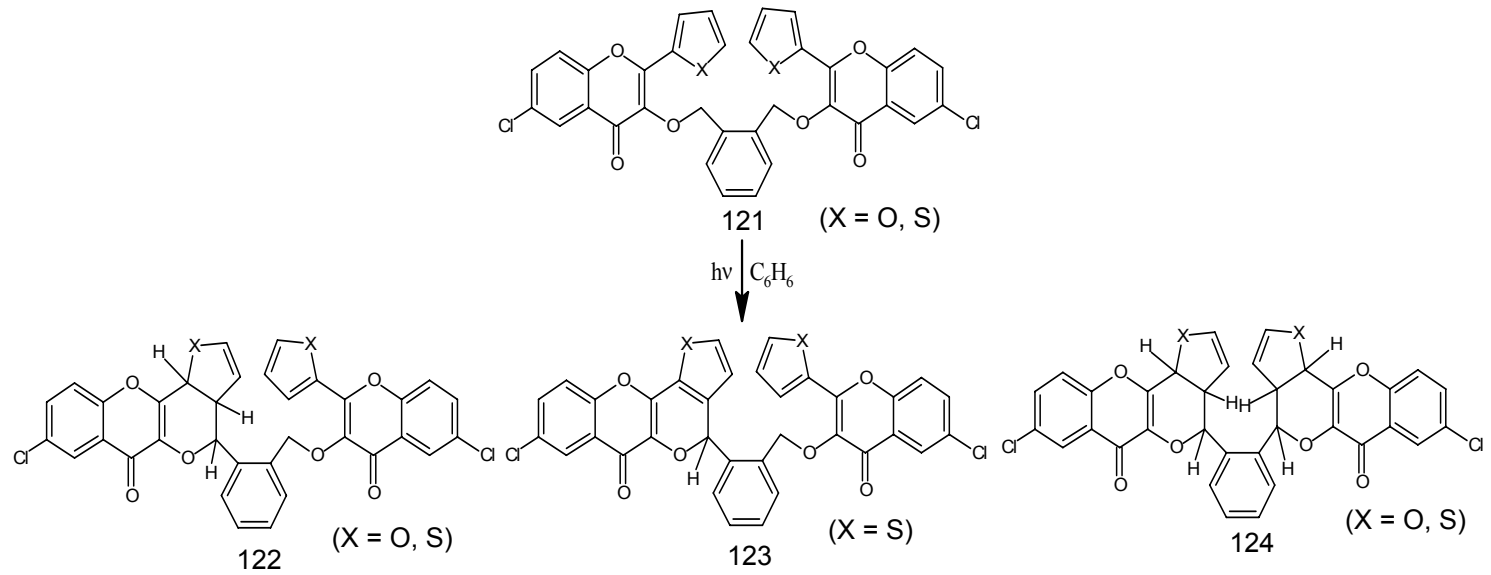

\section{Scheme 37}

The chemical efficiency of these photoreactions was poor as the recovery of the bischromones $\mathbf{1 2 1}$ has been around 80\% and this was inspite of the fact that photoreactions here were initiated through the involvement of benzylic hydrogens. This might be explained on the basis of the ease of intramolecular complex formation between the two units of the substrate that may come in close proximity to each other in one of the conformation leading to the deactivation of the excited molecule. This proximity factor also found support from earlier reports where the bischromone with ethylene ( $\mathrm{n}=0$ in $\mathbf{1 0 1}$ and 109) as spacer failed to undergo any photoreaction whereas in the p-xylene based bischromone, the recovery of substrate was around $40 \%$. In the later, the chromones were too far apart to be involved in complex formation.

\section{Summary}

Chromones and bischromones especially their 3-alkoxy derivatives provide themselves interesting substrates to study their photochemical reactions as these compounds undergo very easy intramolecular $\mathrm{H}$-abstractions to yield numerous important tetracyclic products that are otherwise not possible to prepare under the normal thermal routes. The mild conditions under which these reactions are performed without the use of any precious and toxic reagents means that these synthesis are clearly of immense utilities in the area of synthetic organic chemistry for the development of 
exotic compounds. Thus, these chemical routes present an opportunity for the development of clean and green methods of the product formations.

The photolysis of 3-allyloxy-chromones bearing an electron captive substituent(-COOEt) and 3-cycloalkoxy-chromones offer simple and unique strategies for the synthesis of vinyl ethers and complex spiropyrans respectively. One area in which we see huge synthetic potential is in the bichromones and chromones based cyclophanes. Studies of these cyclophanes will provide an important contribution in the area of host guest relationship and supramolecular photochemistry.

In our present researches, we are focusing to investigate these photo $\mathrm{H}$-abstractions in the bischromones built around trans-2-butenes, 2-butyne, cycloalkenes and heterocyclic rings like pyrrole, thiophene, furan and pyridine. This work will guide us to comment upon the various factors controlling the stabilities of the intermediate 1,4-biradicals and thus the product formations and their distributions in these photoreactions. As such, future of photochemistry of 3-alkoxychromones and bischromones look particularly bright and fruitful.

\section{Acknowledgements}

The Author is highly thankful to Prof. N.R. Dhamiwal, Head, Department of Chemistry, Punjabi University, Patiala for providing the necessary facilities.

\section{References}

1. Ellis, G. P. In Chromenes, Chromanones and Chromones; Weissberger, A.; Taylor, E. C. Eds.; John Wiley \& Sons: New York, 1977; pp 1-10.

2. (a) Cutting, W. C.; Dreisbach, R. H.; Azima, M.; Neff, B. J.; Brown, B. J.; Wray, J. Stanford Med. Bull. 1951, 9, 236. (b) Mentzer, C.; Meunier, P.; Lecocq, J.; Billet, D.; Xuong, D. Bull. Soc. Chim. Fr., 1945, 12, 430. (c) Cox, J. S. G. Nature (London) 1967, 216, 1328. (d) Orr, T. S. C.; Pollard, M. C.; Gwilliam, J.; Cox, J. S. G. Celin. Exp. Immunol. 1970, 7, 745.

3. (a) Bouanani, H.; Gayoso, J. C.R. Acad. Sci. Paris, Ser. C. 1973, 273, 399. (b) Saburi, Y.; Yoshimoto, T.; Minami, K. Nippon Kagaku Zaisshi 1971, 92, 552.

4. Middleton, E.; Kandaswami, C. In The Flavonoids - Advances in Research since 1986 Horbone, J. B. Ed.; Chapman and Hall: London, 1994; pp 619.

5. Spath, E.; Eiter, K. Ber. 1941, 74(B), 1851.

6. Fox, C. H.; Huneck, S. Phytochemistry 1969, 8, 1301.

7. Schmid, H.; Bolleter, A. Helv. Chim. Acta 1949, 32, 1358.

8. Jovanovic, S. V.; Steenken, S.; Tosic, M.; Marjanovic, B.; Simic, M. G. J. Am. Chem. Soc. 1994, 116, 4846. 
9. (a) Sachhar, S. P.; Tripathi, N.; Singh, A. K. Ind. J. Chem. 1987, 26(B), 493. (b) Weidenborner, M.; Hindrof, H.; Jha, H. C.; Tsotsonos, P. Phytochemistry, 1990, 29, 1103. (c) Weidenborner, M., Jha, H. C. Sci. 1993, 38, 347.

10. Grindlay, D.; Reynolds, T. J. Ethnopharmacology 1986, 16, 117.

11. (a) Davis, R. H.; Leitner, M. G.; Ruiso, J. M.; Byrne, M. E. J. Am. Podiatric Med. Assoc. 1989, 79, 263. (b) Udupa, S. L.; Udapa, A. L.; Kulkarni, D. R. Fitoerapia 1994, LXV, 141.

12. Hirata, T.; Suga, T. Bull. Chem. Soc. Jap. 1978, 51, 842.

13. Womble, D.; Helderman, J. H. Int. J. Immunopharmac. 1988, 10, 967.

14. Yu, D.; Brossi, A.; Kilgore, N.; Wild, C.; Alloway, G.; Lee, K. H. Bioorg. Med. Chem. Lett. 2003, 13(9), 1575.

15. Rouwald, H. W.; Brehm, O.; Odenthal, K. P. Planta Med. 1994, 60, 101.

16. (a) Dow, R. L.; Kreutter, D. K. Ann. Rep. Med. Chem. 1995, 30, 159. (b) Lohray, B. B.; Bhushan, V.; Rao, P. B. et al. J. Med. Chem. 1998, 41, 1619. (c) Singh, G.; Singh, L.; Ishar, M. P. S. Tetrahedron 2002, 58, 7883.

17. Hanifin, J. W.; Cohen, E. J. Am. Chem. Soc. 1969, 91, 4494.

18. Turro, N. J. Molecular Photochemistry; W. A. Benjamin Inc.; New York: N.Y. 1965, vol. 46. 19. (a) Hanifin, J. W.; Cohen, E. Tetrahedron lett. 1966, 1419. (b) Blackburn, G. M.; Davis, R. J. H. Chem. Commun. 1965, 215. (c) Hanifin, J. W.; Cohen, E. Tetrahedron lett. 1966, 5421.

20. Gupta, S. C.; Mukerjee, S. M. Tetrahedron Lett. 1973, 51, 5073.

21. (a) Huffman, K. R.; Loy, M.; Ullman, E. F. J. Am. Chem. Soc. 1965, 87, 5417. (b) Henderson Jr., W. A., Ullman, E. F. J. Am. Chem. Soc. 1965, 87, 5424.

22. Sengupta, P. K.; Kasha, M. Chem. Phys. Lett. 1979, 68, 382.

23. (a) Woolfe, G. J.; Thistlewaite, P. J. J. Am. Chem. Soc. 1981, 103, 6916. (b) Itoh, M.; Kurokawa, H. Chem. Phys. Lett. 1982, 91, 487. (c) Itoh, M.; Tokumura, K.; Tanimoto, Y.; Okada, Y.; Takeuchi, H.; Obi, K.; Tanaka, I. J. Am. Chem. Soc. 1982, 104, 4146.

24. (a) Salaman, O. A.; Drickamer, H. G. J. Chem. Phys. 1981, 75, 572. (b) Salaman, O. A.; Drickamer, H. G. J. Chem. Phys. 1982, 77, 3329.

25. Bader, A. N.; Pivovarenko, V.; Demchenko, A. P.; Ariese, F.; Gooijer, C. Spectrochim. Acta A. 2003, 59, 1593.

26. Matsuura, T.; Takemota, T.; Nakashima, R. Tetrahedron 1973, 29, 3337.

27. Woodward, R. B.; Hoffman, R. The Conservation of Orbital Symmetry, 1970, pp 89.

28. Bala, R.; Bansal, W. R.; Yusuf, M. unpublished results.

29. (a) Matsuura, T.; Matsushima, H.; Sakamoto, H. J. Am. Chem. Soc. 1967, 89, 6370. (b) Matsuura, T.; Matsushima, H.; Nakashima, R. Tetrahedron 1970, 26, 435.

30. Ohara, K.; Mukai, K. Chem. Phys. Lett. 2000, 317(6), 619.

31. Bhattacharya, K.; Ramaiah, D.; Das, P. K.; George, M. V. J. Phys. Chem. 1986, 90, 5984.

32. (a) Wargner, P. J. Acc. Chem. Res. 2001, 34(1). (b) Wargner, P. J.; Klan, P. J. Am. Chem. Soc. 1999, 121, 9625. (c) Wagner, P. J.; Sobczak, M.; Park, A. J. Am. Chem. Soc. 1998, 120, 2488. (d) Zond, A.; Park, A.; Wagner, P. J. J. Am. Chem. Soc. 1997, 62, 2326. 
33. (a) Waiss Jr., A. C.; Corse, J. J. Am. Chem. Soc. 1965, 87, 2068. (b) Waiss Jr., A. C.; Lee, A.; Corse, J. J. Am. Chem. Soc. 1967, 89, 6213.

34. Matsuura, T.; Matsushima, H. Tetrahedron 1968, 24, 6615.

35. Yadav, N. S.; Dhawan, S. N.; Gupta, S. C. J. Ind. Chem. Soc. 1990, 67, 770.

36. Gupta, S. C.; Sharma, S.; Saini, A.; Dhawan, S. N. J. Chem. Soc., Perkin Trans 1 1999, 16, 2391.

37. Wynberg, H.; Driel, H. V.; Buler, J. J. Am. Chem. Soc. 1967, 89, 3492.

38. Gupta, S. C.; Saini, A.; Kumar, D.; Yadav, N. S.; Chand, K.; Mor, S.; Dhawan, S. N. J. Chem. Soc., Perkin Trans. 1 1995, 177.

39. Francis, B.; Sherwood, A. G. Can. J. Chem. 1970, 48, 25.

40. Scribe, P.; Nouet, C.; Wieman, J. Tetrahedron Lett. 1970, 4375.

41. Gupta, S. C.; Mukerjee, S. K. Ind. J. Chem. 1973, 11, 1263.

42. Sharma, S. Ph.D. Thesis, Kurukshetra University, Kurukshetra, 1999.

43. Yusuf, M. Ph.D. Thesis, Kurukshetra University, Kurukshetra, 2002.

44. Gupta, S. C.; Yusuf, M.; Sharma, S.; Arora, S. Tetrahedron Lett. 2002, 43, 6875.

45. (a) Anderson, C. M.; Lorsson, J.; Hallberg, A. J. Org. Chem. 1990, 55, 5757. (b) Gassman, P. G.; Burns, S. J. J. Org. Chem. 1988, 53, 5574. (c) Posner, G.H.; Wettlaufer, D. G. J. Am. Chem. Soc. 1986, 108, 7373. (d) Groot, A. De; Jansen, B. J. M. Synth. Commun. 1983, 13, 985.

46. (a) Buehler, C. A.; Pearson, D. E. In Survey of Organic Synthesis, John Wiley and Sons: New York, 1977, Vol. 2, pp 335-344. (b) Pine, S. H.; Zahler, R.; Evans, D. A.; Grubbs, R. H. J. Am. Chem. Soc. 1980, 102, 1980. (c) Marski, M.; Gladysz, J.A. Tetrahedron Lett. 1982, 23, 631. (d) Marsi, M.; Gladysz, J.A. Organometallics 1982, 1, 1467. (e) Vatele, J.M. Tetrahedron Lett. 1984, 25, 5997.

47. Gupta, S. C.; Sharma, S.; Yusuf, M.; Arora, S.; Saini, A.; Kamboj, R. C.; Dhawan, S. N. J. Chem. Res.(s) 2002, 165.

48. Steer, R. P.; Ramamurthy, V. Acc. Chem. Res. 1988, 21, 380.

49. Maciejewski, K.; Szymanski, M.; Steer, R. P. Chem. Phys. 1988, 124, 143.

50. (a) Gupta, S. C.; Yusuf, M.; Sharma, S.; Saini, A.; Arora, S.; Kamboj, R. C. Tetrahedron 2004, 60, 8445. (b) Gupta, S. C.; Yadav, N. S.; Dhawan, S. N. Ind. J. Chem. 1991, 30(B), 790.

51. (a) Mazzucato, U. Pure Appl. Chem. 1982, 54, 1705. (b) Laarhoven, W. H. Rec. J.R. Neth. Chem. Soc. 1983, 185 and 241.

52. Mallory, F. B.; Mallory, C. W. Organic Reactions, John Wiley Sons: New York 1984, Vol. $1, \mathrm{p} 30$.

53. Feigenbaum, A.; Fort, Y.; Pete, J. P.; Scholler, D. J. J. Org. Chem. 1986, 51, 4424.

54. Chabers, M. S.; Baker, R.; Bilington, D. C.; Knight, A. K.; Middlemiss, D. N.; Wong, E. H. F. J. Med. Chem. 1992, 35, 2033. 
55. (a) Dessauer, R.; Paris, J. P. Advances in Photochemistry, 1963, 1, 275. (b) Chauhan, M. S.; Kinnin, D. M. Can. J. Chem. 1981, 59, 2223. (c) Cacioli, P.; Mackay, M. F. J. Reiss, Tetrahedron Lett. 1980, 4973. (d) Kave, H. J. Synthesis 1979, 886.

56. Gupta, S. C.; Saini, A.; Sharma, S.; Kapoor, M.; Dhawan, S. N. Tetrahedron Lett. 1996, 37, 8913.

57. Kumar, R.; Yusuf, M. unpublished results.

58. Wagner, P. J. J. Am. Chem. Soc. 1970, 4, 168.

59. (a) Cox, J. S. G. Adv. Drug Res. 1970, 5, 177. (b) Chem. Abstr. 1967, 100002.

60. (a) Harnish, H. Liebigs Ann. Chem. 1972, 8, 765. (b) Glozman, S. M.; Troitskaya, V. S.; Vinokurov, V. G.; Zagorevskii, V. A. Chem. Heterocycl. Compd. 1969, 19, 5. (c) Ermili, A.; Roma, G.; Balbi, A. Farm., Ed. Sci. 1974, 29, 247. (d) Hazard, R.; Wall, E. N. Brit. Patent, 1973, 1, 324, 571.

61. (a) Chem. Abstr. 1973, 79, 126313. (b) Dean, F. M.; Frankham, D. B.; Hatanm, N.; Hill, A. W. J. Chem. Soc. 1969, C, 704.

62. (a) Barber, G.; Ellis, G. P.; Shaw, D. J. Med. Chem. 1973, 16, 87. (b) Bandyopadhyay, C.; Sur, R. K.; Das, H. K. J. Chem. Res., Synop. I 1999, 598, 2561.

63. Gupta, S. C.; Yusuf, M.; Arora, S.; Sharma, S.; Kamboj, R. C.; Dhawan, S. N. Tetrahedron, 2002, 58, 3095.

64. Leenders, L.; De Schryver, F.C. Angew. Chem. 1971, 83, 359.

65. Leenders, L.; Schouteden, E.; De Schryver, F. C. J. Org. Chem. 1973, 38, 957.

66. Gervaisand, J.; De Schryver, F. C. Photochem. Photobiol. 1975, $21,71$.

67. Shimo, T.; Veda, S.; Suish, T.; Somekawa, K. J. Het. Chem. 1995, 727.

68. (a) Nath, A.; Mal, J.; Venkateswaran, R. V. J. Org. Chem. 1996, 61, 4391. (b) Nath, A.; Venkateswaran, R. V. J. Chem. Soc. Chem. Commun. 1993, 281.

69. Gupta, S. C.; Yusuf, M.; Arora, S.; Kamboj, R. C. Tetrahedron 2003, 59, 3609.

70. Gupta, S. C.; Yusuf, M.; Thakur, M.; Kamboj, R. C. J. Chem. Res.(s) 2005, 741.

\section{Author's Biographical data}

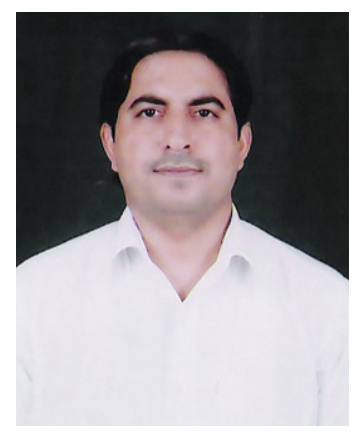

Mohamad Yusuf obtained his post graduation degree in Organic Chemistry from the Kurukshetra University, Kurukshetra, India in 1997. Afterwards he earned his doctorate degree in chemistry 
from the same university under the co-supervision of Prof. S. C. Gupta and Prof. S. N. Dhawan in 2002. Further, he spent one year in the Department of Chemistry, Guru Jambheshar University, Hisar, as a member of teaching faculty. In Aug. 2003, he occupied a permanent position, as a lecturer of Organic Chemistry in the Department of Chemistry, Punjabi University, Patiala. His current research interest includes the solution phase as well as solid phase photochemistry of chromones, bichromones, bischromones and dialkoxyanthraquinones.

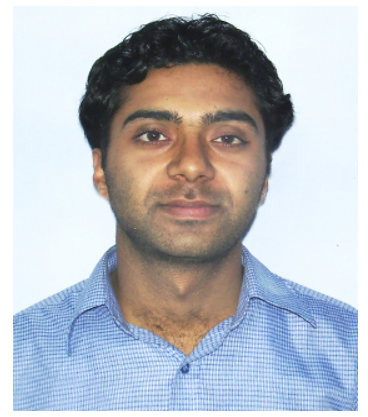

Rupesh Kumar is a graduate of the Panjab University, Chandigarh, India. Afterwards he completed his postgraduation in Organic Chemistry from Department of Chemistry, Punjabi University, Patiala, India. In 2004, he started his Ph.D. programme on the "Synthesis and Photochemistry of Chromones and Bischromones" in the same department under the supervision of Dr. Mohamad Yusuf. 